\title{
Effects of feeding frequency and oil supplementation on feeding behavior, ruminal fermentation, digestibility, blood metabolites, and milk performance in late-lactation cows fed a high-forage diet
}

\author{
Hamidreza Mirzaei-Alamouti, ${ }^{1} \odot$ Kamran Akbari-Pabandi, ${ }^{1}$ () Morteza Mansouryar, ${ }^{2}$ Mohammad Ali Sirjani, ${ }^{1} \odot$ \\ Adam Cieslak, ${ }^{3}$ ( ) Malgorzata Szumacher-Strabel, ${ }^{3}$ Amlan Kumar Patra, ${ }^{4}{ }^{\circ}$ and Mina Vazirigohar ${ }^{5 *}$ (1) \\ ${ }^{1}$ Department of Animal Science, University of Zanjan, Zanjan 45371-38791, Iran \\ ${ }^{2}$ Department of Veterinary and Animal Sciences, Faculty of Health and Medical Sciences, University of Copenhagen, Grønnegårdsvej 3 , \\ 1870 Frederiksberg C, Denmark \\ ${ }^{3}$ Department of Animal Nutrition, Poznan University of Life Sciences, Wolynska 33, 60-637 Poznan, Poland \\ ${ }^{4}$ Department of Animal Nutrition, West Bengal University of Animal and Fishery Sciences, $37 \mathrm{~K}$. B. Sarani, Belgachia, Kolkata, India 700037 \\ ${ }^{5}$ Zist Dam Group, University Incubator Center, University of Zanjan, Zanjan 45371-38791, Iran
}

\begin{abstract}
Many dairy producers are keen to feed low-producing late-lactation cows only once per day $(1 \times)$ to reduce production costs. This study examined effects of feeding frequency (FF: thrice versus once daily) on behavioral patterns, ruminal fermentation, and milk production performance of cows and supplementation of yellow grease oil (YO) rich in 18:2n-6 as a potential strategy to alleviate the possible negative effects of $1 \times$ daily feeding. Twenty-four late-lactation Holstein cows $(215 \pm 53.8 \mathrm{DIM})$ housed in tiestalls were assigned to 4 treatments according to a $2 \times 2$ factorial arrangement with $2 \mathrm{FF}$ [ 3 times daily $(3 \times)$ at 0800,1400 , and $2000 \mathrm{~h}$; or $1 \times$ at $0800 \mathrm{~h}$ ] and 2 high-forage total mixed rations (TMR), without (CON) or with $25 \mathrm{~g} / \mathrm{kg}$ of dry matter of YO (YGO), in a randomized complete block design. Treatments were applied for $21 \mathrm{~d}$. Feeding behavior was recorded every 5 min over a 24-h period on d 19 . Fresh TMR and orts were sampled (d 15 to 21) and separated using a 3 -screen $(19,8$, and $1.18 \mathrm{~mm})$ Penn State Particle Separator for sorting activity. Ruminal fluid samples were collected using oral stomach tubing on $\mathrm{d} 21$. Cows on $1 \times-\mathrm{CON}$ spent more time eating during the first $6 \mathrm{~h}$ after feeding at $0800 \mathrm{~h}$ than did cows on $3 \times-\mathrm{CON}$ or $1 \times-\mathrm{YGO}$. Decreasing FF increased meal length and tended to increase meal size for CON cows, but supplementing YO increased meal bouts and reduced meal length and size for cows fed $1 \times$. Cows on $1 \times$-CON had the greatest ruminating time between 2000 and $0800 \mathrm{~h}$ compared with other treatments. Total and daytime distribution of lying time did not vary by treatments. Sorting activity was higher for cows
\end{abstract}

Received May 9, 2020.

Accepted August 7, 2020.

*Corresponding author: mvaziri@ut.ac.ir fed frequently, and the extent of sorting was increased by oil supplementation. In the morning ruminal fluid samples, $\mathrm{pH}$ was not different among treatments, but in the evening samples $1 \times$ daily feeding reduced ruminal $\mathrm{pH}$ compared with $3 \times$. In the morning and evening samples, ratios of acetate to propionate were the lowest for $1 \times-\mathrm{CON}$ cows compared with other treatments. Dry matter intake and milk yield were similar among the groups. Milk fat content and yield decreased with $1 \times-\mathrm{CON}$ treatment, but supplementing YO numerically increased milk fat for cows fed $1 \times$. These results suggest that decreasing $\mathrm{FF}$ from $3 \times$ to $1 \times$ daily increases meal length, particularly after feed delivery, in cows fed high-forage diets; but supplementation of plant oil changes feeding patterns and may improve ruminal $\mathrm{pH}$ and milk fat in cows fed once a day.

Key words: behavior, dairy cow, feeding frequency, plant oil

\section{INTRODUCTION}

Delivery of fresh feed is the strongest stimulus for eating activity in lactating dairy cattle (DeVries and von Keyserlingk, 2005). Feeding cows once per day $(1 \times)$ might result in "slug" feeding, a significant peak in eating activity after feed delivery (DeVries et al., 2005), and therefore a peak in fermentation of ingested materials in the rumen, which may predispose cows to SARA (Macmillan et al., 2017). Feeding cows several times each day distributes eating activity throughout the day (Phillips and Rind, 2001; DeVries et al., 2005 ) and reduces the diurnal variation in ruminal $\mathrm{pH}$ (French and Kennelly, 1990; Macmillan et al., 2017). This feeding practice may improve fiber digestibility (Dhiman et al., 2002), milk fat content (Macmillan et al., 2017), and production efficiency (Mäntysaari et al., 2006) compared with cows fed once a day. 
The positive effects on ruminal health of increasing feed delivery frequency would be expected to be greater in high-producing cows receiving high-concentrate diets (French and Kennelly, 1990; Shabi et al., 1999; Dhiman et al., 2002; Mäntysaari et al., 2006), which are more susceptible to SARA (Macmillan et al., 2017). In contrast, frequent feeding may have minor effects on digestibility or ruminal fermentation of lactating cows receiving high-forage diets (>650 g/kg DM; Robinson and Sniffen, 1985). However, increasing forage inclusion rate in dairy cattle diets increases sorting against the forage components (Miller-Cushon and DeVries, 2017). Ruminal health can be optimized and feed sorting minimized when cows consume smaller meals, slowly and frequently (Humer et al., 2018). It has been shown that providing feed more than once a day might reduce sorting behavior (DeVries et al., 2005; Macmillan et al., 2017).

Supplementation of dietary fat is a common practice to increase dietary energy density of high-yielding lactating cows. Including fat supplement enriched unsaturated fatty acids (FA) in high-forage diets improves milk FA composition without adverse effects on milk fat yield (Bell et al., 2006; Shingfield et al., 2008; Cieslak et al., 2015). Short-term feeding behavior can be regulated by the type and temporal pattern of absorbed nutrients (Tolkamp et al., 2000). Including fat supplement, particularly rich in unsaturated FA, in the diets of cattle can act as a physiological signal in the duodenum and may stimulate satiety (Choi and Palmquist, 1996; Benson and Reynolds, 2001; Bradford et al., 2008). Therefore, feeding plant oil supplements may be a strategy to decrease meal size or increase meal interval (Harvatine and Allen, 2006; Kargar et al., 2010), similar to increased feed delivery frequency, to reduce the risk of acidosis by decreasing amounts of fermentable substrates entering the rumen. Moreover, it has been indicated that addition of various liquids, such as plant oils, molasses, or water, to a TMR can reduce feed-sorting behavior (Owens and Basalan, 2016; Miller-Cushon and DeVries, 2017).

In most commercial dairy farms, TMR is delivered 2 to 4 times per day for high-producing lactating cows. However, many producers are keen to feed the low-producing late-lactation cows only once a day, to reduce management costs. We hypothesized that under high forage-based diets, which is a routine feeding practice of late-lactation cows, (1) offering diets once daily would change the meal pattern in a way that would negatively influence ruminal health and lactation performance of cows compared with feeding thrice daily $(\mathbf{3} \times)$, and $(2)$ including a plant oil in the diet of cows fed $1 \times$ daily can be considered as a possible management approach that may encourage cows to distribute their eating time more evenly throughout the day. The objective of this study was to examine the possible interaction between feed delivery frequency and supplementation of yellow grease oil (YO, residual frying oil; Kargar et al., 2010, 2012) rich in 18:2n-6 on feeding behavior, ruminal fermentation, total-tract digestibility, blood metabolites, and milk production and composition in late-lactation cows fed a high-forage diet.

\section{MATERIALS AND METHODS}

\section{Animals and Treatments}

Twenty-four late-lactation Holstein dairy cows, consisting of 12 primiparous and 12 multiparous $[622 \pm$ $43.5 \mathrm{~kg}$ BW, $2.1 \pm 1.35$ parity, $215 \pm 53.8 \mathrm{DIM}$, and $22.4 \pm 2.92 \mathrm{~kg} / \mathrm{d}$ milk production (mean $\pm \mathrm{SD}$ )], were selected from the Dairy Research Farm of the University of Zanjan (Zanjan, Iran). Cows were allocated to 2 blocks according to parity. Within each block, cows were divided into 3 groups of 4 , which were balanced according to DIM and milk production. Within each group of 4 , cows were randomly assigned to 4 treatments, as follows: (1) offering $3 \times$ daily a high-forage diet (forage-to-concentrate ratio of 60:40, DM basis) without fat supplement $(\mathbf{C O N} ; \mathbf{3} \times \mathbf{- C O N}),(2)$ offering $3 \times$ daily a high-forage diet containing $25 \mathrm{~g} / \mathrm{kg} \mathrm{DM}$ of YO supplement (YGO; $3 \times-\mathbf{Y G O}$ ), (3) offering the CON diet once daily $(\mathbf{1} \times \mathbf{- C O N})$, or (4) offering the YGO diet once daily $(\mathbf{1} \times$-YGO; Table 1$)$. The experiment lasted $28 \mathrm{~d}$ : 7-d baseline and 21-d treatment periods (14-d adaptation and 7-d measurement periods). During the baseline period, to obtain covariate data, all cows received a TMR similar to the CON diet fed to the cows during the experiment (Table 1). The YO supplement contained $53 \%$ of $18: 2 \mathrm{n}-6 \mathrm{FA}$ of total FA (Table 1) and was premixed with concentrate fraction before inclusion in the TMR. The YGO diet was prepared by replacing wheat bran with $\mathrm{YO}$ and increasing the proportion of soybean meal to adjust dietary CP. All diets were formulated using the Cornell-Penn-Miner system (CPM-Dairy, version 3.0.7; http://www.cpmdairy.com) to meet or exceed the nutrient requirements of cows in late lactation producing $30 \mathrm{~kg}$ of milk/d. The TMR was prepared manually once daily, at approximately $0700 \mathrm{~h}$, and offered at $0800 \mathrm{~h}$ for $1 \times$ treatments and as equal meals at 0800 (morning), 1400 (afternoon), and 2000 $\mathrm{h}$ (evening) for $3 \times$ treatments, ensuring ad libitum intakes (i.e., $10 \%$ orts as fed). The DM concentration of corn silage was determined weekly, and diets were adjusted when necessary. Cows were housed in individual tiestalls, bedded with wood shavings as needed, and 
with free access to fresh water. Cows on 2 different feed delivery frequencies $(3 \times$ and $1 \times)$ were housed indoors in 2 rows with a back-to-back layout and a wide passage (approximately $7 \mathrm{~m}$ ) between them. Both sides had similar lighting and ventilation arrangements. The feeds were offered manually from the passages at the head side of cows. Staff were trained to deliver feeds with the least possible noise, to minimize stimulating the cows fed $1 \times$ daily to consume feed by the cows fed $3 \times$ daily. Cows were milked twice daily (0700 and $1900 \mathrm{~h}$ ) in a herringbone milking parlor with 6 milking units, spending a maximum of $2 \mathrm{~h} / \mathrm{d}$ outside the pen for milking. Cows were weighed after the morning milking on 2 consecutive days immediately before the start of the treatment period. The experiment was conducted from September 23 to October 23, and the average environmental temperature during the data collection period was $15 \pm 5.5^{\circ} \mathrm{C}$. All experimental procedures

Table 1. Ingredients and chemical composition of diets fed to latelactating dairy cows

\begin{tabular}{|c|c|c|}
\hline \multirow[b]{2}{*}{ Item } & \multicolumn{2}{|c|}{ Treatment $^{1}$} \\
\hline & $\mathrm{CON}$ & YGO \\
\hline \multicolumn{3}{|l|}{ Ingredient, $\mathrm{g} / \mathrm{kg} \mathrm{DM}$} \\
\hline Corn silage & 350 & 350 \\
\hline Alfalfa hay & 250 & 250 \\
\hline Ground barley & 161 & 161 \\
\hline Soybean meal & 111 & 125 \\
\hline Wheat bran & 111 & 72 \\
\hline Yellow grease oil ${ }^{2}$ & - & 25 \\
\hline Calcium carbonate & 8.3 & 8.3 \\
\hline Mineral and vitamin premix ${ }^{3}$ & 5.6 & 5.6 \\
\hline Salt & 2.8 & 2.8 \\
\hline \multicolumn{3}{|c|}{ Chemical composition, $\mathrm{g} / \mathrm{kg}$ of DM } \\
\hline DM, g/kg as fed & 500 & 500 \\
\hline $\mathrm{OM}$ & 916 & 915 \\
\hline $\mathrm{CP}$ & 152 & 152 \\
\hline $\mathrm{NDF}$ & 365 & 350 \\
\hline Ether extract & 28.4 & 53.4 \\
\hline $\mathrm{NE}_{\mathrm{L}}, \mathrm{Mcal} / \mathrm{kg}$ of $\mathrm{DM}^{4}$ & 1.52 & 1.64 \\
\hline \multicolumn{3}{|l|}{ Particle size distribution, ${ }^{5} \%$} \\
\hline Long & 27.4 & 23.6 \\
\hline Medium & 30.8 & 37.0 \\
\hline Short & 28.5 & 28.5 \\
\hline Fine & 13.3 & 11.0 \\
\hline
\end{tabular}

${ }^{1}$ Treatments consisted of high-forage (forage-to-concentrate ratio of 60:40, DM basis) diets without (CON) or containing $25 \mathrm{~g} / \mathrm{kg}$ of DM yellow grease oil supplement (YGO).

${ }^{2}$ Residual frying oil (kitchen by-product) containing (g/100 g of total fatty acids) 16:0 (11.0), 18:0 (3.85), cis-9 18:1 (25.4), 18:2n-6 (53.2), and 18:3n-3 (6.01).

${ }^{3}$ Declared as containing ( $\mathrm{g} / \mathrm{kg}$ of DM) Ca (196), P (96), Na (46), Mg (19), $\mathrm{Cu}$ (3), Fe (3), Zn (3), Mn (2), Co (0.1), I (0.1), Se (0.001), antioxidant $(0.4) ;(\mathrm{IU} / \mathrm{g})$ vitamin $\mathrm{A}(3,000)$, vitamin $\mathrm{D}(800)$, and vitamin $\mathrm{E}(6)$.

${ }^{4}$ Calculated using NRC (2001) equations.

${ }^{5}$ Particle size determined using the Penn State Particle Separator, which had 19-mm (long), 8-mm (medium), and 1.18-mm (short) screens and a pan (fine). were approved by the Animal Care Committee of the University of Zanjan (Zajan, Iran, ID no. 1353).

\section{Measurements and Sample Collection}

The amounts of fresh TMR offered and refused (orts) were recorded daily during baseline and treatment periods. Samples of orts for each cow and the fresh TMR for each treatment were collected in duplicate at 0730 and $0800 \mathrm{~h}$, respectively, during the measurement period (d 15 to 21) for DM, chemical, and particle size analysis. Once collected, TMR and orts samples were immediately stored at $-20^{\circ} \mathrm{C}$ until submitted for analysis. Daily milk yields were recorded throughout the baseline and measurement periods. Milk samples were collected at each milking from all cows on d 15, 17, and 19 of the treatment period, preserved with potassium dichromate (Merck KGaA, Darmstadt, Germany), stored at $4^{\circ} \mathrm{C}$, and pooled according to milk yield before being analyzed for fat, CP, lactose, and MUN via infrared analysis (MilkoScan 4000; Foss, Hillerød, Denmark) and for SCC by the flow cytometry method (Fossomatic 4000; Foss Electric, Hillerød, Denmark).

Individual chewing and resting activities were monitored visually over a 24 -h period on d 19 of the treatment period. These activities were recorded by 5 -min interval observations, and each activity was assumed to persist for the entire 5-min interval (Beauchemin et al., 2003). To determine how the cows spent time for eating, ruminating, and lying, relative to feed delivery, the respective behaviors were summarized separately for 3 time periods (time periods 1, 2, and 3 were 0800 to $1400 \mathrm{~h}, 1400$ to $2000 \mathrm{~h}$, and 2000 to $0800 \mathrm{~h}$, respectively) relative to the $3 \times$ daily feeding schedule. A meal was defined as at least one observation of eating activity occurring after at least 20 min without eating activity (Wangsness et al., 1976). Periods of ruminating or lying were defined as at least 5 min of ruminating or lying occurring after at least $5 \mathrm{~min}$ without these respective activities. The feed sorting index was calculated as the ratio of actual intake to predicted intake of particles retained on each sieve of the Penn State Particle Separator, expressed as a percentage. The actual intake of each fraction was calculated as the difference between the DM amount of each fraction in the offered TMR and that in the orts. The predicted intake for each fraction was calculated as the product of the total DMI multiplied by the DM percentage of that fraction in the offered TMR. A sorting index above 100 indicated sorting for particles, and an index below 100 indicated sorting against particles (Leonardi and Armentano, 2003).

On d 20 of the treatment period, before morning feeding, blood samples $(10 \mathrm{~mL})$ were collected from 
the coccygeal vein into sterile tubes (BD Vacutainer; Becton Dickinson and Company, Franklin Lakes, NJ) containing sodium heparin (200 United States Pharmacopeia units). Samples were immediately placed on ice and centrifuged within $1 \mathrm{~h}$ at $3,000 \times g$ for 15 min at $4^{\circ} \mathrm{C}$; plasma was harvested and stored at $-20^{\circ} \mathrm{C}$ until further analysis. Colorimetric methods were used to determine the plasma concentrations of glucose (kit number 017-500-1), albumin (kit number 001-500-1), and total cholesterol (kit number 010-500-1) following manufacturer protocols (Pars Azmun Co., Tehran, Iran).

On d 20 of the treatment period, spot fecal samples were also taken at 4 -h intervals over a 24 -h period, starting at $0830 \mathrm{~h}$, and stored at $-20^{\circ} \mathrm{C}$ until being submitted for chemical analysis. Apparent total-tract digestibility was estimated using acid-insoluble ash as an internal marker (Van Keulen and Young, 1977). Ruminal fluid samples were collected from all cows on d 21 of the treatment period, within 2 to $4 \mathrm{~h}$ after morning $(0800 \mathrm{~h})$ and afternoon $(1400 \mathrm{~h})$ feedings relative to the $3 \times$ feeding schedule, using a stomach tube attached to an Erlenmeyer flask connected to a vacuum pump. The initial $300 \mathrm{~mL}$ of each ruminal fluid sample was discarded, to minimize saliva contamination. After collection $(300 \mathrm{~mL})$, samples were filtered through 4 layers of cheesecloth, and $\mathrm{pH}$ was determined immediately using a portable $\mathrm{pH}$ meter (Kent EIL 7020; Kent, Bridgwater, UK). An 8-mL aliquot of the filtered ruminal fluid was acidified with $2 \mathrm{~mL}$ of $25 \%$ metaphosphoric acid containing $2 \mathrm{~g} / \mathrm{L}$ of 2-ethyl butyric acid (an internal standard; Sigma-Aldrich, Hamburg, Germany) and stored at $-20^{\circ} \mathrm{C}$ for VFA analysis.

\section{Laboratory Analysis}

Thawed TMR, orts, and fecal samples were dried in a forced-air oven at $60^{\circ} \mathrm{C}$ for $48 \mathrm{~h}$ and milled through a 1-mm screen (Retsch mill; Retsch Co., Haan, Germany). Subsequently TMR and fecal samples were composited by treatment and cow, respectively, and ort samples of each cow $(7$ samples/cow) were pooled on an ort amount basis. Pooled TMR, orts, and fecal samples were analyzed for analytical $\mathrm{DM}\left(105^{\circ} \mathrm{C}\right.$ oven for 24 $\mathrm{h}$ ), ash $\left(550^{\circ} \mathrm{C}\right.$ furnace for $6 \mathrm{~h}$ ), nitrogen (Kjeltec 1030 Autoanalyzer; Foss Tecator AB, Höganäs, Sweden), and ether extract (EE; Soxtec 1043; Foss, Denmark; AOAC, 1990). Concentrations of acid-insoluble ash were determined following sequential acid hydrolysis (Van Keulen and Young, 1977). Concentrations of NDF were determined using heat-stable $\alpha$-amylase and sodium sulfite (Van Soest et al., 1991) in an Ankom 200 Fiber Analyzer (Ankom Technology Corp., Fair- port, NY) and reported on an ash-free basis. Thawed TMR and ort samples collected for particle size separation were pooled (by treatment and cow for TMR and orts, respectively) and separated using a 3-screen $(19,8$, and $1.18 \mathrm{~mm}$ ) separator (Kononoff et al., 2003) without oven drying, which separated the particles into 4 fractions: long (>19 mm), medium $(19-8 \mathrm{~mm})$, short $(8-1.18 \mathrm{~mm})$, and fine $(<1.18 \mathrm{~mm})$. Chemical composition and particle size distribution of diets are shown in Table 1.

Ruminal fluid samples were analyzed for short-chain FA as described by Mirzaei-Alamouti et al. (2016). Briefly, samples preserved with metaphosphoric acid were thawed, and a $5-\mathrm{mL}$ aliquot of the supernatant was transferred into a $15-\mathrm{mL}$ glass test tube and centrifuged (Mikro 220R; Hettich, Germany) at 10,000 $\times$ $g$ for 15 min at $4^{\circ} \mathrm{C}$. A $1-\mu \mathrm{L}$ aliquot of upper phase was injected into a gas chromatograph (Varian 3400; Varian Inc., Walnut Creek, CA) equipped with an injector at $170^{\circ} \mathrm{C}$, a flame-ionization detector at $175^{\circ} \mathrm{C}$, and a packed column $(2-\mathrm{m}$ length $\times 2$-mm inner diameter, glass containing 1-1965 $10 \% \mathrm{SP}-1200 / 1 \% \quad \mathrm{H}_{3} \mathrm{PO}_{4}$ on 80/100 mesh Chromosorb W; Sigma-Aldrich). The temperature of the GC oven was isothermic and maintained at $140^{\circ} \mathrm{C}$. Gas flow rates were 40 and $300 \mathrm{~mL} /$ min for nitrogen and compressed air, respectively.

\section{Statistical Analysis}

Intake, milk yield, and milk composition data were averaged by cow before analysis. Intake, milk yield, and blood metabolite data were analyzed with a model that included the fixed effects of feeding frequency $(\mathbf{F F})$, oil supplementation, interaction between $\mathrm{FF}$ and oil supplementation, and the respective covariate, and random effects of block (parity) and cow within interaction between FF and oil supplementation using PROC MIXED of SAS (SAS 9.2; SAS Institute Inc., Cary, $\mathrm{NC}$ ). We removed the nonsignificant respective covariates from the model based on model fit criteria. Feeding behavior, feed sorting activity, ruminal fermentation, digestibility, and milk composition data were analyzed using the same model without a covariate. When the interaction effect was significant $(P \leq 0.05)$ or tended to be significant $(0.05<P \leq 0.10)$, pair-wise differences between means were explored using Tukey's test. Least squares means are reported, and treatment effects were declared significant or tended to be significant at $P \leq$ 0.05 and $0.05<P \leq 0.10$, respectively. To test whether sorting of the experimental treatments occurred, sorting activity for each fraction of the Penn State Particle Separator was summarized by treatment and tested for a difference from 100 using PROC TTEST of SAS. 


\section{RESULTS}

The $P$-values reported in the tables are not repeated, but the $P$-values derived from the pair-wise comparisons of Tukey's test are reported here.

\section{Feeding Behavior}

Decreasing frequency of feeding $(3 \times$ vs. $1 \times)$ had no effect on total eating time, regardless of YO supplementation (Table 2). However, an interaction between $\mathrm{FF}$ and $\mathrm{YO}$ supplementation was found for eating time at time period 1 , in which $1 \times$ daily feeding increased $(P=0.03)$ eating time between 0800 and $1400 \mathrm{~h}$ for CON cows with no difference for YGO cows (Table 2). Differences among the 4 treatments regarding the daily continuous distribution of eating time are illustrated in Figure 1. An interaction between $\mathrm{FF} \times$ YO supplementation was also found on meal patterns (Table 2$)$. Feeding $1 \times$ daily increased $(P=0.04)$ meal length and tended $(P=0.08)$ to increase meal size for CON cows, whereas it increased $(P=0.01)$ meal bouts and decreased $(P=0.04)$ meal length for YGO cows (Table 2). The differences between treatments in the number of meals and meal lengths throughout the day are also illustrated in Figure 1. The duration of the first meal after morning milking (at $0700 \mathrm{~h}$ ) tended to be greater for cows fed $1 \times$ than cows fed $3 \times$ daily, regardless of YO supplementation (Table 2). We observed a tendency for an interaction between FF and oil supplementation on the largest meal, where CON cows had a larger $(P=0.02)$ meal than YGO cows when fed $1 \times$ (Table 2 ). Feeding $1 \times$ daily had no effect on total ruminating time, regardless of YO supplementation, compared with $3 \times$ feeding (Table 2 ). However, FF and an interaction between FF and oil supplementation influenced ruminating time between 2000 and $0800 \mathrm{~h}$, where the $1 \times-\mathrm{CON}$ cows had the greatest $(P \leq 0.03)$ ruminating time in this period compared with the other groups (Table 2). We observed differences in neither total lying time nor distribution of lying time throughout the day, although an interaction between FF and YO supplementation was found for lying bouts, which numerically decreased $(P=0.18)$ in the $1 \times-\mathrm{CON}$ cows but numerically increased $(P=0.14)$ in the $1 \times-\mathrm{YGO}$ cows (Table 2 and Figure 2).

Long particles $(>19.0 \mathrm{~mm})$ were refused $(P<0.01)$ and medium particles (19 to $8 \mathrm{~mm})$ were selected $(P$ $<0.01$ ) by cows on all treatments, and the magnitude of this selecting increased with the inclusion of oil in the diet (Table 3). Short particles $(8-1.18 \mathrm{~mm})$ were selected $(P<0.01)$ on all treatments with no effect of FF or oil supplementation on the extent of this sorting behavior (Table 3$)$. Cows sorted $(P \leq 0.02)$ in favor of fine particles $(<1.18 \mathrm{~mm})$ when fed $3 \times$ daily, and the degree of this sorting increased with YO supplementation (Table 3$)$. Cows sorted $(P<0.01)$ against NDF in the diets, with the exception of cows receiving $1 \times-\mathrm{YGO}$ treatment; neither FF nor oil supplementation had an effect on the extent of this sorting (Table 3).

\section{Ruminal Fermentation}

For morning ruminal fluid samples, $\mathrm{pH}$ and total VFA concentrations were not affected by treatment (Table 4). Molar proportion of acetate was decreased $(P<0.01)$ and propionate was increased $(P<0.01)$ with $1 \times$ daily feeding for CON cows, but this effect was not found for YGO cows (Table 4). We also observed a tendency for an interaction between FF and YO supplementation on molar proportion of valerate (Table 4).

For evening ruminal fluid samples, $1 \times$ daily feeding decreased ruminal $\mathrm{pH}$ compared with $3 \times$ feeding, regardless of YO supplementation (Table 4). An interaction between FF and YO supplementation tended to influence total VFA concentration (Table 4). We also found an interaction between FF and oil supplementation on molar proportions of acetate and propionate, where including $\mathrm{YO}$ in the diet increased $(P<0.01)$ molar proportion of acetate and decreased $(P<0.01)$ propionate for cows fed $1 \times$ but not for cows fed $3 \times$ (Table 4). Molar proportions of butyrate and valerate were lower for cows fed $1 \times$ compared with cows fed $3 \times$ (Table 4). No influence of FF or interaction between FF and oil supplementation on molar proportion of isobutyrate was observed, but isobutyrate proportion was greater for YGO cows than for CON cows (Table 4).

\section{Intake and Digestibility}

Feeding frequency and interaction between FF and oil supplementation had no effects on DM, OM, CP, or NDF intakes, but oil supplementation tended to decrease OM intake, decreased NDF intake, and increased EE intake (Table 5). We observed no effects of treatment on total-tract digestibility of $\mathrm{OM}, \mathrm{CP}, \mathrm{NDF}$, or EE, but YGO cows had lower total-tract digestibility of $\mathrm{CP}$ and greater total-tract digestibility of EE than the CON cows (Table 5).

\section{Blood Metabolites and Milk Production Performance}

We observed no difference in plasma glucose, albumin, or total cholesterol concentrations (Table 6). Differences in milk, FCM, or ECM yields were also not found (Table 6). However, an interaction between FF and oil supplementation was noted for milk fat yield 


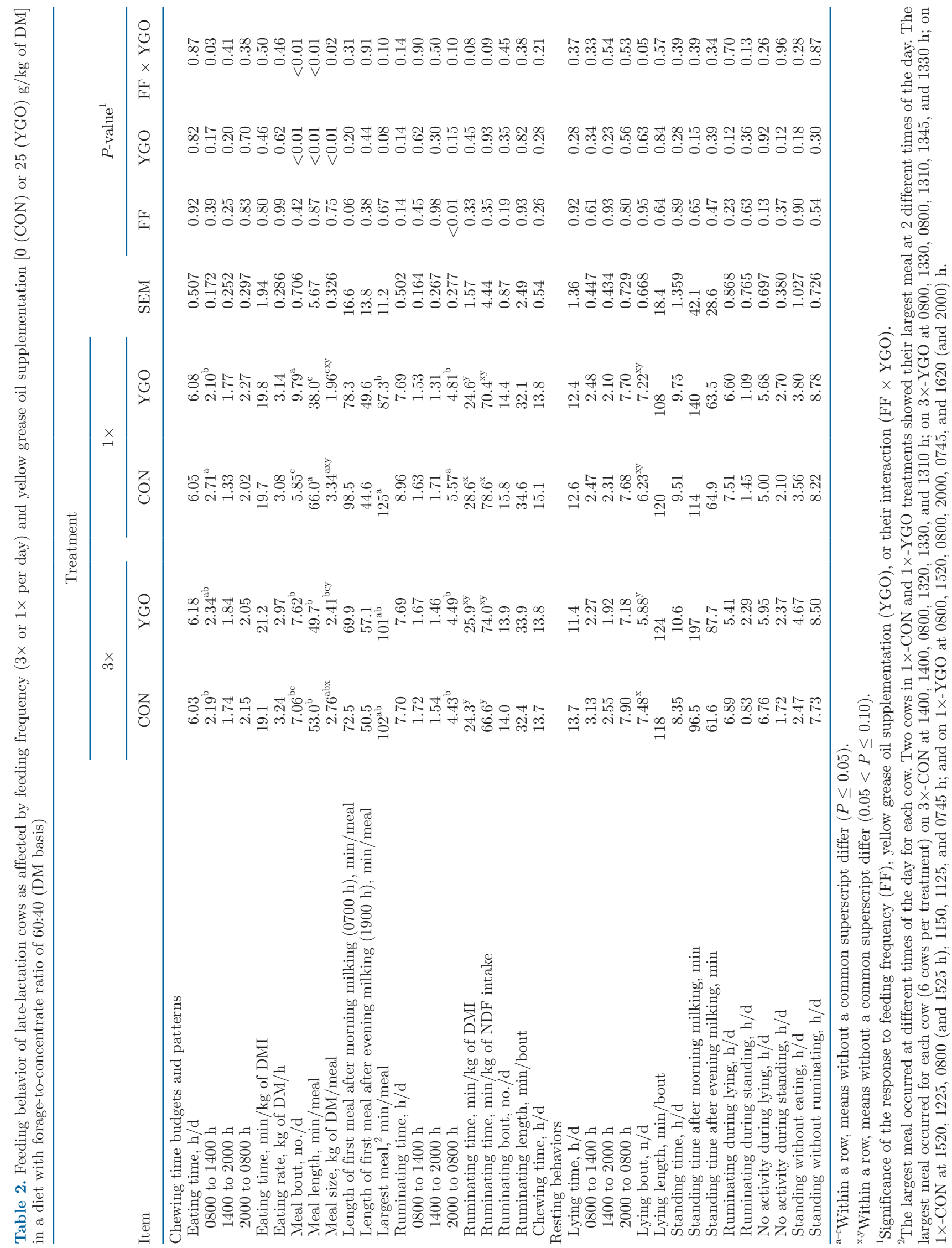


$3 x-C O N$
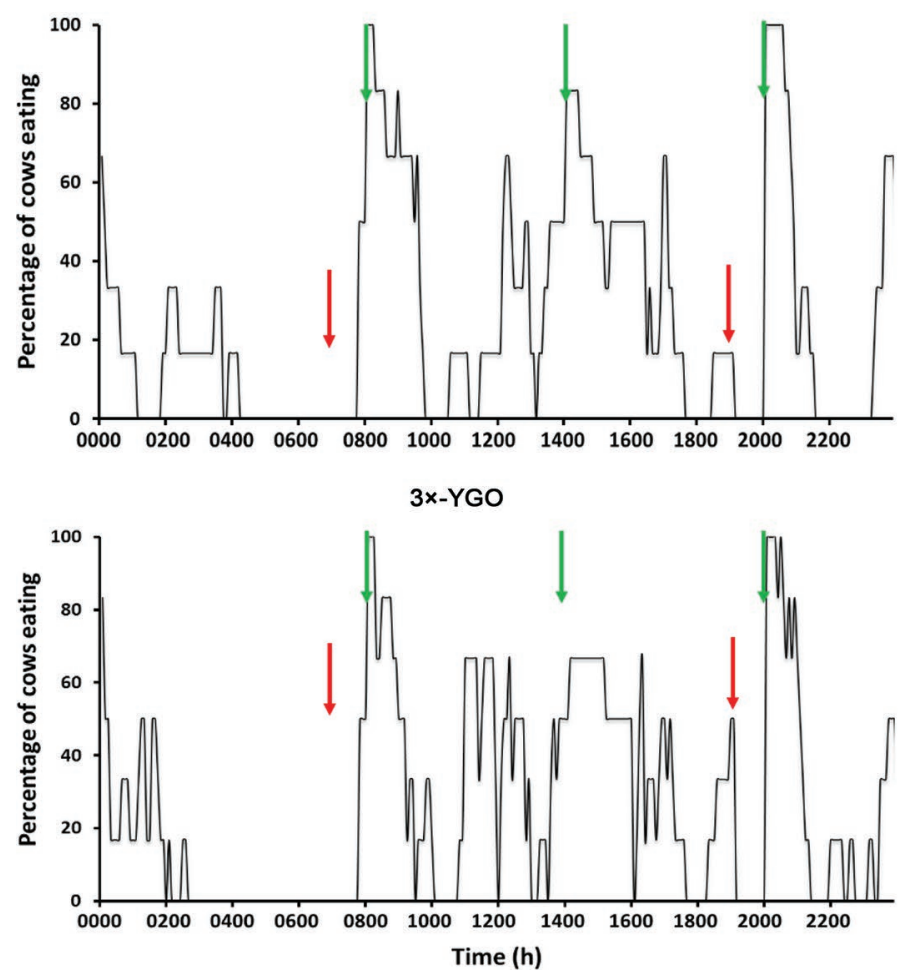

$1 \times-C O N$
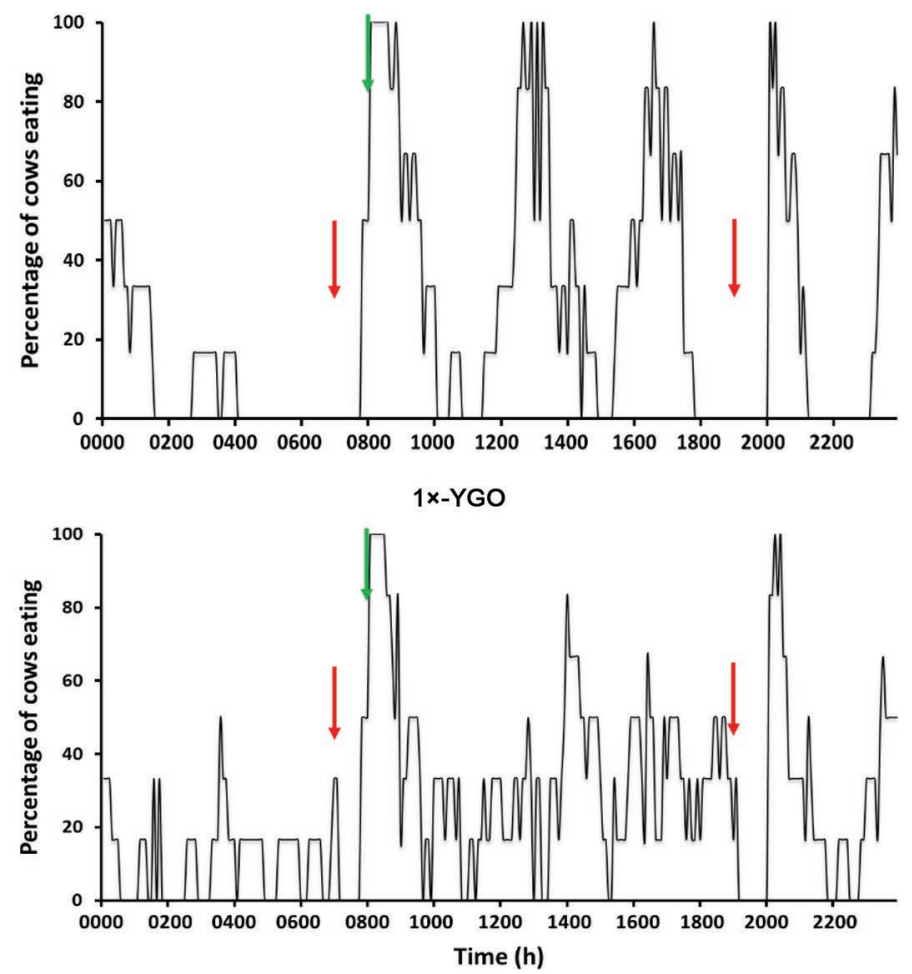

Figure 1. Percentage of cows eating over a 24-h period (percentage for each 5-min interval during the day) as affected by feeding frequency $(3 \times$ daily, at 0800,1400 , and $2000 \mathrm{~h}$; or $1 \times$ daily, at $0800 \mathrm{~h})$ and yellow grease oil supplementation $[0(\mathrm{CON}) \mathrm{or} 25(\mathrm{YGO}) \mathrm{g} / \mathrm{kg}$ of $\mathrm{DM}] \mathrm{in}$ a diet with forage-to-concentrate ratio of 60:40 (DM basis). Green arrows show feeding times, and red arrows show milking times (0700 and 1900 h). Number of cows in each treatment was 6 .

and milk fat content, in which $1 \times$ feeding decreased $(P$ $\leq 0.02$ ) both milk fat yield and content for CON cows with no differences for YGO cows (Table 6). An interaction between FF and YO supplementation tended to affect milk protein content, where oil supplementation lowered $(P=0.02)$ milk protein content in cows fed $3 \times$ but not in cows fed $1 \times$ daily (Table 6 ). We also did not observe differences in milk protein yield, milk lactose content or yield, MUN, or milk SCC (Table 6).

\section{DISCUSSION}

Many dairy producers opt to deliver feeds more than once per day to high-producing dairy cows and only once daily to low-producing late-lactation cows. The objectives of this study were to determine whether decreasing feed delivery frequency (i.e., $3 \times$ vs. $1 \times$ ) affects the feeding behavior, ruminal fermentation, and milk production of late-lactation cows, and whether the possible negative effects of feeding $1 \times$ daily on these responses could be alleviated by inclusion of plant oil in the diet. The absence of any negative responses in ruminal health and production performance with offering TMR $1 \times$ daily in the current study may suggest that the extra time, effort, and cost required for more frequent feeding to low-producing lactating cows fed a forage-based diet might not be justified.

\section{Feeding Behavior}

In the present study, total eating time was not influenced by frequency of feed delivery. Also, feeding $1 \times$ versus $4 \times$ daily in low-producing cows did not affect daily eating time (Phillips and Rind, 2001). However, with high-producing dairy cows, daily eating time increased with increased frequency of feed delivery (Shabi et al., 1999; DeVries et al., 2005; Mäntysaari et al., 2006). These conflicting effects in the literature may partly be attributed to differences in intake and production levels of cows. Cows with low milk production and consequently lower nutrient demands, similar to cows used in the present study, may not have the same motivation to consume feeds in response to increased frequency of feed delivery, by increasing their eating time, as much as cows with high milk production and DMI. When cows are housed in the same pen, the high-frequency treatment may stimulate the cows on the low-frequency treatment to eat, which is known as 
$3 \times-C O N$
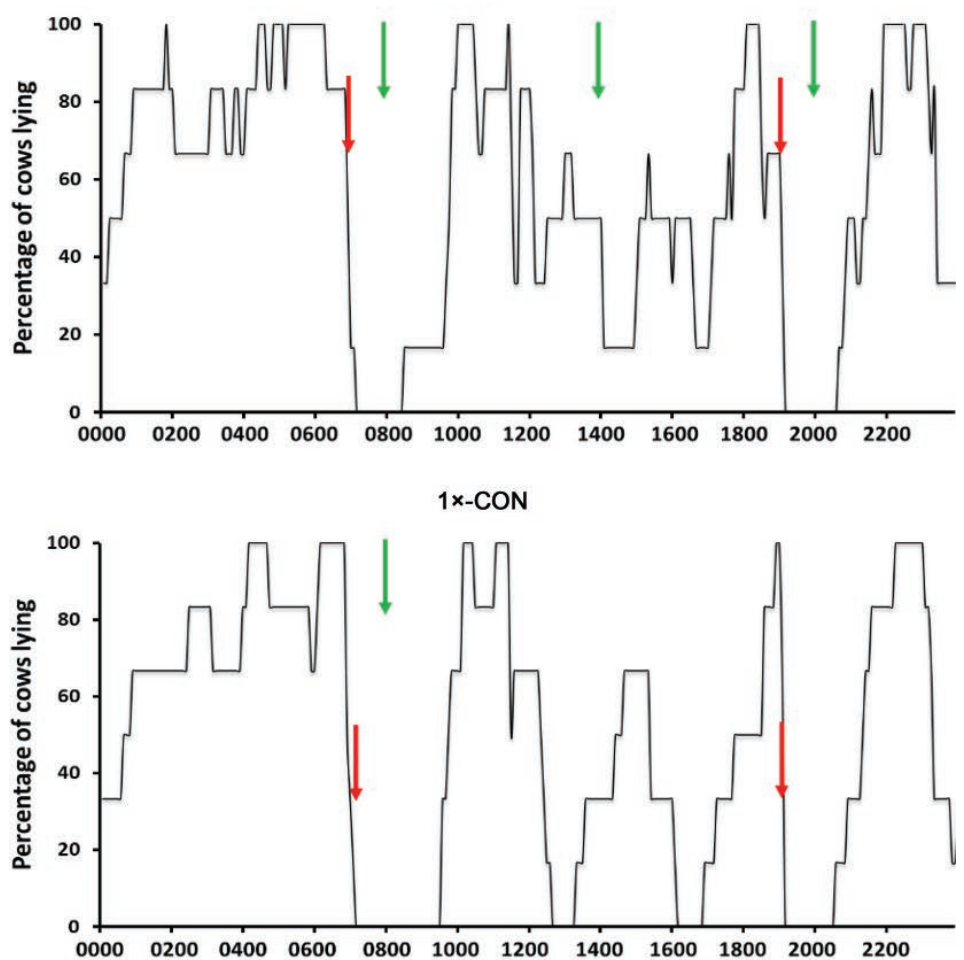

$3 \times-Y G O$

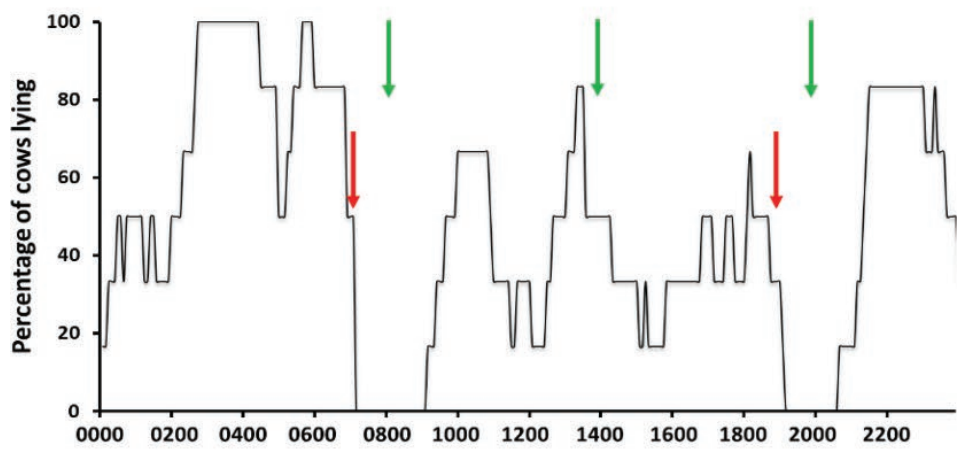

$1 \times-Y G O$

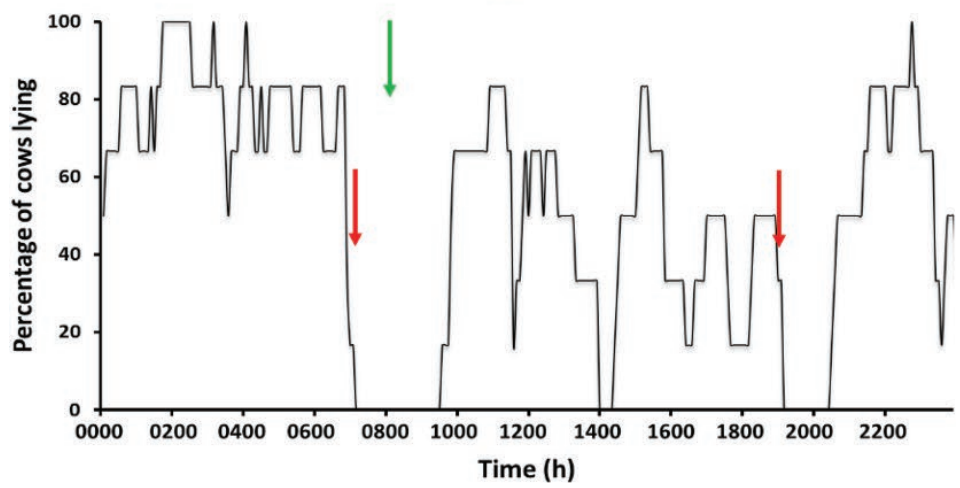

Figure 2. Percentage of cows lying over a 24-h period (percentage for each 5-min interval during the day) as affected by feeding frequency ( $3 \times$ daily, at 0800,1400 , and $2000 \mathrm{~h}$; or $1 \times$ daily, at $0800 \mathrm{~h}$ ) and yellow grease oil supplementation $[0(\mathrm{CON})$ or $25(\mathrm{YGO}) \mathrm{g} / \mathrm{kg}$ of $\mathrm{DM}] \mathrm{in}$ a diet with forage-to-concentrate ratio of 60:40 (DM basis). Green arrows show feeding times, and red arrows show milking times (0700 and 1900 h). Number of cows in each treatment was 6 . 
Table 3. Feed sorting of late-lactation cows as affected by feeding frequency $(3 \times$ or $1 \times$ per day) and yellow grease oil supplementation $[0$ (CON) or $25(\mathrm{YGO}) \mathrm{g} / \mathrm{kg}$ of $\mathrm{DM}]$ in a diet with forage-to-concentrate ratio of $60: 40$ (DM basis) ${ }^{1}$

\begin{tabular}{|c|c|c|c|c|c|c|c|c|}
\hline \multirow{2}{*}{ Item } & \multicolumn{4}{|c|}{ Treatment } & \multirow{2}{*}{ SEM } & \multirow{2}{*}{\multicolumn{3}{|c|}{$P$-value ${ }^{2}$}} \\
\hline & \multicolumn{2}{|c|}{$3 \times$} & \multicolumn{2}{|c|}{$1 \times$} & & & & \\
\hline \multicolumn{9}{|c|}{ Particle fraction, ${ }^{3} \%$} \\
\hline Long & $89.7^{*}$ & $84.1^{*}$ & $88.5^{*}$ & $86.1^{*}$ & 3.36 & 0.79 & $<0.01$ & 0.26 \\
\hline Medium & $103.9^{*}$ & $105.3^{*}$ & $104.0^{*}$ & $104.6^{*}$ & 0.79 & 0.43 & 0.03 & 0.36 \\
\hline Dietary NDF & $96.5^{*}$ & $95.4^{*}$ & $95.8^{*}$ & 97.5 & 1.28 & 0.46 & 0.72 & 0.17 \\
\hline
\end{tabular}

*Difference $(P \leq 0.05)$ in individual sorting values (within treatment) from $100 \%$.

${ }^{1}$ Sorting index was calculated as the ratio of actual intake to predicted intake for particles retained on each sieve of the separator, expressed in percentage. A sorting index equal to 100 indicated no sorting, above 100 indicated sorting for particles, and below 100 indicated sorting against particles (Leonardi and Armentano, 2003).

${ }^{2}$ Significance of the response to feeding frequency $(\mathrm{FF})$, yellow grease oil supplementation (YGO), or their interaction $(\mathrm{FF} \times \mathrm{YGO})$.

${ }^{3}$ Particle size determined via Penn State Particle Separator, which had 19-mm (long), 8-mm (medium), and 1.18-mm (short) screens and a pan (fine).

social facilitation (Curtis and Houpt, 1983), resulting in lack of differences in behavioral responses (Crossley et al., 2018). In the current study, cows were housed individually, and $2 \mathrm{FF}$ treatments were allocated in a way (as discussed earlier) intended to reduce social facilitation.
Although total eating time was not affected, the distribution of eating activity throughout the day was influenced by the interaction between $\mathrm{FF}$ and oil supplementation in the present study. The cows on $1 \times-$ CON spent more time eating between 0800 and 1400 h compared with $3 \times-\mathrm{CON}$ or $1 \times-\mathrm{YGO}$ cows. These

Table 4. Ruminal fermentation parameters of late-lactation cows as affected by feeding frequency $(3 \times$ or $1 \times$ per day $)$ and yellow grease oil supplementation $[0(\mathrm{CON})$ or $25(\mathrm{YGO}) \mathrm{g} / \mathrm{kg}$ of $\mathrm{DM}]$ in a diet with forage-to-concentrate ratio of 60:40 (DM basis)

\begin{tabular}{|c|c|c|c|c|c|c|c|c|}
\hline \multirow[b]{2}{*}{ Item } & \multicolumn{4}{|c|}{ Treatment } & \multirow[b]{2}{*}{ SEM } & \multicolumn{3}{|c|}{$P$-value ${ }^{1}$} \\
\hline & $\mathrm{CON}$ & YGO & $\mathrm{CON}$ & YGO & & $\mathrm{FF}$ & YGO & $\mathrm{FF} \times \mathrm{YGO}$ \\
\hline \multicolumn{9}{|l|}{ Morning } \\
\hline $\mathrm{pH}$ & 6.55 & 6.56 & 6.61 & 6.70 & 0.209 & 0.48 & 0.69 & 0.78 \\
\hline Total VFA, mmol/L & 96.4 & 102.5 & 92.3 & 110.6 & 7.90 & 0.80 & 0.14 & 0.45 \\
\hline Butyrate (B), mol/100 mol & 13.6 & 14.9 & 14.6 & 13.8 & 1.72 & 0.92 & 0.78 & 0.22 \\
\hline Valerate, ${ }^{2} \mathrm{~mol} / 100 \mathrm{~mol}$ & 2.05 & 2.24 & 2.26 & 2.02 & 0.181 & 0.98 & 0.85 & 0.10 \\
\hline Isobutyrate, $\mathrm{mol} / 100 \mathrm{~mol}$ & 1.20 & 1.43 & 1.36 & 1.58 & 0.412 & 0.43 & 0.25 & 0.99 \\
\hline $\mathrm{A}: \mathrm{P}$ & $3.69^{\mathrm{a}}$ & $3.78^{\mathrm{a}}$ & $2.87^{\mathrm{b}}$ & $4.09^{\mathrm{a}}$ & 0.416 & 0.15 & $<0.01$ & $<0.01$ \\
\hline$(\mathrm{A}+\mathrm{B}): \mathrm{P}$ & $4.44^{\mathrm{a}}$ & $4.64^{\mathrm{a}}$ & $3.55^{\mathrm{b}}$ & $4.89^{\mathrm{a}}$ & 0.421 & 0.18 & $<0.01$ & 0.03 \\
\hline \multicolumn{9}{|l|}{ Evening } \\
\hline $\mathrm{pH}$ & 6.54 & 6.48 & 6.19 & 6.35 & 0.102 & 0.02 & 0.58 & 0.24 \\
\hline Isobutyrate, $\mathrm{mol} / 100 \mathrm{~mol}$ & 0.50 & 0.92 & 0.50 & 0.94 & 0.151 & 0.96 & 0.01 & 0.94 \\
\hline $\mathrm{A}: \mathrm{P}$ & $3.48^{\text {aby }}$ & $3.39^{\text {bxyz }}$ & $2.79^{\mathrm{bcz}}$ & $4.21^{\mathrm{ax}}$ & 0.266 & 0.81 & 0.02 & 0.01 \\
\hline$(\mathrm{A}+\mathrm{B}): \mathrm{P}$ & $4.35^{\mathrm{abxy}}$ & $4.30^{\mathrm{bcx}}$ & $3.42^{\mathrm{cy}}$ & $5.01^{\operatorname{axy}}$ & 0.304 & 0.72 & 0.02 & 0.02 \\
\hline
\end{tabular}

${ }^{\mathrm{a}-\mathrm{c}}$ Within a row, means without a common superscript differ $(P \leq 0.05)$.

${ }^{\mathrm{x}-\mathrm{z}}$ Within a row, means without a common superscript differ $(0.05<P \leq 0.10)$.

${ }^{1}$ Significance of the response to feeding frequency (FF), yellow grease oil supplementation $(\mathrm{YGO})$, or their interaction $(\mathrm{FF} \times \mathrm{YGO})$.

${ }^{2}$ Interaction effects showed a tendency $(P \leq 0.10)$, but Tukey's test did not show significance at $P \leq 0.10$. 
Table 5. Intake and nutrient total-tract digestibility of late-lactation cows as affected by feeding frequency $(3 \times$ or $1 \times$ per day $)$ and yellow grease oil supplementation $[0(\mathrm{CON})$ or $25(\mathrm{YGO}) \mathrm{g} / \mathrm{kg}$ of $\mathrm{DM}]$ in a diet with forage-to-concentrate ratio of 60:40 (DM basis)

\begin{tabular}{|c|c|c|c|c|c|c|c|c|}
\hline \multirow{2}{*}{ Item } & \multicolumn{4}{|c|}{ Treatment } & \multirow{2}{*}{ SEM } & \multirow{2}{*}{\multicolumn{3}{|c|}{$P$-value ${ }^{1}$}} \\
\hline & \multicolumn{2}{|c|}{$3 \times$} & \multicolumn{2}{|c|}{$1 \times$} & & & & \\
\hline \multicolumn{9}{|l|}{ Intake, $\mathrm{kg} / \mathrm{d}$} \\
\hline DM & 19.1 & 17.6 & 18.5 & 18.6 & 0.75 & 0.61 & 0.12 & 0.11 \\
\hline $\mathrm{OM}$ & 17.5 & 16.1 & 17.0 & 17.0 & 0.68 & 0.67 & 0.10 & 0.14 \\
\hline Ether extract & $0.54^{\mathrm{b}}$ & $0.92^{\mathrm{a}}$ & $0.53^{\mathrm{b}}$ & $0.99^{\mathrm{a}}$ & 0.022 & 0.24 & $<0.01$ & 0.07 \\
\hline \multicolumn{9}{|c|}{ Digestibility, $\mathrm{g} / \mathrm{kg}$} \\
\hline $\mathrm{OM}$ & 722 & 683 & 682 & 663 & 29.1 & 0.45 & 0.21 & 0.57 \\
\hline $\mathrm{CP}$ & 787 & 740 & 771 & 717 & 23.4 & 0.39 & 0.03 & 0.87 \\
\hline $\mathrm{NDF}$ & 503 & 417 & 451 & 407 & 53.6 & 0.56 & 0.23 & 0.70 \\
\hline Ether extract & 919 & 931 & 903 & 927 & 11.6 & 0.17 & 0.02 & 0.39 \\
\hline
\end{tabular}

${ }^{\mathrm{a}, \mathrm{b}}$ Within a row, means without a common superscript differ $(P \leq 0.05)$.

${ }^{1}$ Significance of the response to feeding frequency $(\mathrm{FF})$, yellow grease oil supplementation $(\mathrm{YGO})$, or their interaction $(\mathrm{FF} \times \mathrm{YGO})$.

results suggest that cows fed $1 \times-\mathrm{CON}$ possibly had greater rumen capacity during that period compared with the 2 other groups. Feeding motivation decreases throughout the day, potentially due to rumen fill (Hart et al., 2014). Dürst et al. (1993) suggested that eating activities during the daytime occur in response to external stimuli such as feeding time, milking, and the eating activity of other cows, whereas eating at night occurs in response to the requirement for energy and its influence on appetite. In the Niu et al. (2014) study, approximately $63 \%$ of feed was consumed during the first $12 \mathrm{~h}$ after feeding in the $1 \times$-fed (morning feeding) cows, which was comparable to our results $(67 \%$ of total eating time for $1 \times-\mathrm{CON}$ cows occurred between 0800 and $2000 \mathrm{~h}$ ). In other studies, frequent feed delivery also resulted in a more even distribution of eating time over

Table 6. Blood metabolites and milk production performance of late-lactation cows as affected by feeding frequency $(3 \times$ or $1 \times$ per day) and yellow grease oil supplementation $[0(\mathrm{CON})$ or $25(\mathrm{YGO}) \mathrm{g} / \mathrm{kg}$ of $\mathrm{DM}]$ in a diet with forage-to-concentrate ratio of 60:40 (DM basis)

\begin{tabular}{|c|c|c|c|c|c|c|c|c|}
\hline Item & \multicolumn{4}{|c|}{ Treatment } & SEM & \multicolumn{3}{|c|}{$P$-value ${ }^{1}$} \\
\hline \multicolumn{9}{|l|}{ Blood metabolites } \\
\hline Glucose, mg/dL & 52.6 & 54.9 & 49.6 & 52.8 & 11.7 & 0.21 & 0.15 & 0.82 \\
\hline Albumin, g/dL & 3.91 & 4.48 & 4.19 & 4.09 & 0.685 & 0.81 & 0.24 & 0.12 \\
\hline Milk, $\mathrm{kg} / \mathrm{d}$ & 20.1 & 21.2 & 20.9 & 20.9 & 1.13 & 0.63 & 0.29 & 0.26 \\
\hline $3.5 \% \mathrm{FCM}^{2} \mathrm{~kg} / \mathrm{d}$ & 21.5 & 19.8 & 19.1 & 20.1 & 1.17 & 0.29 & 0.73 & 0.16 \\
\hline $\mathrm{ECM},{ }^{3} \mathrm{~kg} / \mathrm{d}$ & 19.8 & 18.0 & 17.7 & 18.5 & 1.04 & 0.29 & 0.54 & 0.13 \\
\hline Fat, $\mathrm{g} / \mathrm{d}$ & $773^{\mathrm{ax}}$ & $662^{\text {aby }}$ & $627^{\text {bxy }}$ & $692^{\text {abxy }}$ & 49.7 & 0.15 & 0.56 & 0.04 \\
\hline Protein, g/d & 679 & 615 & 640 & 633 & 36.4 & 0.71 & 0.20 & 0.30 \\
\hline Lactose, $\mathrm{g} / \mathrm{d}$ & 940 & 939 & 913 & 924 & 68.2 & 0.57 & 0.90 & 0.87 \\
\hline \multicolumn{9}{|l|}{ Milk composition } \\
\hline
\end{tabular}

${ }^{\mathrm{a}-\mathrm{c}}$ Within a row, means without a common superscript differ $(P \leq 0.05)$.

${ }^{\mathrm{x}, \mathrm{y}}$ Within a row, means without a common superscript differ $(0.05<P \leq 0.10)$.

${ }^{1}$ Significance of the response to feeding frequency $(\mathrm{FF})$, yellow grease oil supplementation $(\mathrm{YGO})$, or their interaction $(\mathrm{FF} \times \mathrm{YGO})$.

${ }^{2} 3.5 \% \mathrm{FCM}=(0.4324 \times \mathrm{kg}$ of milk yield $)+(16.216 \times \mathrm{kg}$ of milk fat yield $)$.

${ }^{3} \mathrm{ECM}=$ milk yield $\times(383 \times$ fat $\%+242 \times$ protein $\%+783.2) / 3140($ Sjaunja et al., 1990 $)$.

${ }^{4} \mathrm{SCC}($ cells $/ \mathrm{mL})$ were log-transformed. 
the course of the day (DeVries et al., 2005; Mäntysaari et al., 2006; Macmillan et al., 2017).

In agreement with previous studies reporting no difference in meal patterns for cattle fed $1 \times$ compared with $3 \times$ daily (Hart et al., 2014), we observed no effect of feed delivery frequency on meal patterns. However, YO supplementation increased meal frequency and reduced meal duration and size. Supplemental fats, especially rich in unsaturated FA, may cause a hypophagic effect and physiologically signal (Choi and Palmquist, 1996; Benson and Reynolds, 2001; Bradford et al., 2008) to decrease meal size or length (Harvatine and Allen, 2006). It has been suggested that consumption of smaller and more frequent meals throughout the day is beneficial for cows (Humer et al., 2018). In an earlier study (De Visser et al., 1982), mid-lactation cows offered a high-concentrate diet supplemented with saturated fat (at $75 \mathrm{~g} / \mathrm{kg}$ of diet DM) consumed the supplemented concentrate feed with a greater frequency, in smaller quantities, and at a slower rate compared with the unsupplemented concentrate. Heinrichs et al. (1982) observed a decrease in the size of the initial meal after supplementation of tallow; however, the number of subsequent meals was increased, with no difference in DMI. In the study of Kargar et al. (2010), supplementation of $20 \mathrm{~g} / \mathrm{kg}$ DM of YO had no effect on meal bouts or size among dairy cows receiving a high-concentrate diet twice daily, which might be attributed to the diet difference between the studies (i.e., a high-concentrate vs. a high-forage diet).

In some studies, an increase in rumination time was observed following an increase in feed delivery frequency (Acatincai et al., 2010; Crossley et al., 2018). This greater rumination time has the potential to positively affect ruminal health by stimulating saliva production and increasing ruminal buffering capacity (Beauchemin et al., 2008). In the present study, total time spent ruminating was similar among treatments, although lower frequency of feed delivery increased ruminating time between 2000 and $0800 \mathrm{~h}$, and the $1 \times-\mathrm{CON}$ cows had the greatest ruminating time at this time period. This is comparable to the findings of Hart et al. (2014), who reported no difference in daily total rumination time but observed an alteration across the day. Depressed ruminal $\mathrm{pH}$ increases rumination (DeVries et al., 2009) to enhance buffering activity in the rumen (Johnston and DeVries, 2018). Similarly in the present study, ruminal $\mathrm{pH}$ in the evening was lower for cows fed $1 \times$ compared with cows fed $3 \times$ daily, which perhaps increased ruminating activity between 2000 and $0800 \mathrm{~h}$.

Lying time is relatively consistent among dairy cows, who tend to modify other behaviors, even feeding, to conserve this time (Munksgaard et al., 2005). In this study, lower frequency of feed delivery had no effect on total lying time. Reports in the literature conflict regarding the effects of feed delivery frequency on lying bouts. Cows exhibited more frequent bouts of lying when feed delivery was increased from 2 to 4 times a day (DeVries et al., 2005). In the study of Hart et al. (2014), no effect on lying bouts was observed for once compared with 3 times daily feeding. In the current study, lower frequency of feed delivery in cows fed the CON diet numerically ( 7.48 vs. $6.23 / \mathrm{d} ; P=0.18$ ) decreased number of lying bouts, and supplementation of $\mathrm{YO}$ in the diet of cows fed $1 \times$ did not affect this behavior.

Cows selectively sort smaller components of the TMR across the day (Leonardi and Armentano, 2003; DeVries et al., 2005). The level of sorting can be reduced by increasing TMR delivery frequency; however, responses may depend on experimental design of studies, group or individual housing, or diet composition. In the study of DeVries et al. (2005), group-housed cows fed once daily sorted more, and orts contained $8 \%$ more forage, than cows fed twice a day. In the current study, sorting activity was higher for cows fed frequently; cows fed $3 \times$ sorted (i.e., significant differences from 100\%) against long particles and in favor of medium, short, and fine particles, whereas cows fed $1 \times$ sorted against long particles and in favor of medium and short particles in the TMR. In other studies, with individual (Macmillan et al., 2017) or group (Crossley et al., 2018) feeding conditions, sorting behavior did not change with increased FF. Addition of $\mathrm{YO}$ changed the DM particle distribution of the ration, resulting in a lower proportion of long and fine particles and a greater proportion of medium particles. Supplementation of oil in the TMR increased the extent of sorting against long and in favor of medium and fine particles among cows fed $3 \times$, which can possibly be attributed to the YO adhering to the medium and fine particles (because the oil was premixed with the concentrate fraction before inclusion in the TMR), but had no effect on sorting in cows fed $1 \times$. To our knowledge, this is the first study to report sorting activity with the supplementation of plant oil in the diet, based on actual and predicted amounts of particles consumed. However, other studies examining addition of other liquid feeds, such as water or molasses, to the TMR for decreasing sorting behavior have shown variable responses depending on DM content and forage proportion of ration (Miller-Cushon and DeVries, 2017).

\section{Ruminal Fermentation}

Effects of $\mathrm{FF}$ on ruminal $\mathrm{pH}$ can be attributed to a change in eating pattern. When changes in $\mathrm{pH}$ were monitored during a 24 -h period, a dramatic decrease 
in ruminal $\mathrm{pH}$ was observed following each feeding for the low FF compared with the high FF (French and Kennelly, 1990; Le Liboux and Peyraud, 1999). In the current study, cows fed $1 \times$ tended to eat the first meal after delivery of feed at $0800 \mathrm{~h}$ for a longer time compared with the cows fed $3 \times$, but no differences were observed in the $\mathrm{pH}$ of morning ruminal samples. These responses can partly be explained by the greater time spent for ruminating during the 12 -h period before feed delivery on the next day (2000 to $0800 \mathrm{~h}$ ) for low FF $(1 \times)$, which was in agreement with a previous report (Macmillan et al., 2017). In addition, the diets used in this study contained a high proportion of forage, which was not as effective as a high-concentrate diet to reduce ruminal $\mathrm{pH}$. Moreover, a difference in the distribution of eating time may not always lead to a similar difference in the distribution of feed intake, although we did not measure the DMI for each meal. Dado and Allen (1994) showed that daily eating time and total DMI were not highly correlated. In this study, supplementation of YO to the CON cows fed $1 \times$ numerically (6.19 vs. $6.35 ; P$ $=0.23$ ) increased ruminal $\mathrm{pH}$ in the evening, which can be attributed to a change in meal pattern. In other studies, feeding diets containing $20 \mathrm{~g} / \mathrm{kg}$ of DM of plant oil once per day reduced (Ramirez Ramirez et al., 2016) or did not alter (Alfonso-Avila et al., 2017) ruminal pH compared with control diets.

In the current study, feeding CON cows $1 \times$ decreased molar proportion of acetate and increased molar proportion of propionate in the morning and evening ruminal fluid samples. In previous studies (French and Kennelly, 1990; Macmillan et al., 2017), ruminal VFA concentrations and individual VFA proportions were not affected by FF. We collected ruminal fluid samples via oral stomach tube at 2 different times (morning and evening), but in previous studies (French and Kennelly, 1990; Macmillan et al., 2017) ruminal fermentation characteristics were recorded more continuously via ruminal cannula; therefore, our data need to be interpreted suitably. Nevertheless, our previous work showed that molar VFA proportion data, collected using a stomach tube, can be reliable to use, because they were highly associated with milk odd- and branched-chain FA (Vazirigohar et al., 2018). It has also been shown that ruminal fermentation variables and microbial composition are usually similar for samples collected via oral stomach tubing, rumenocentesis, or ruminal cannula (Lodge-Ivey et al., 2009; Shen et al., 2012). Moreover, the molar proportions of ruminal VFA are usually less sensitive to site and time of sampling than to ruminal VFA production rate (Morvay et al., 2011). Supplemental fats usually reduce acetate-to-propionate ratio (Patra, 2013, 2014; Pi et al., 2019) due to inhibitory effects of fats on ru- minal cellulolytic bacteria and fiber digestion (Patra and $\mathrm{Yu}, 2013$ ). In a recent meta-analysis (Weld and Armentano, 2017), unsaturated plant oils were found to exert only a small negative effect (1.2 percentage units) on total-tract NDF digestibility, and the effect was relatively unimportant at levels of oils typically added in diets (up to $30 \mathrm{~g} / \mathrm{kg}$ diet $\mathrm{DM}$ ). Moreover, supplementation of 16- or 18-carbon fats do not appear to have significant effects on ruminal NDF digestibility at these levels (Weld and Armentano, 2017). Similarly, in the current study, YO at $20 \mathrm{~g} / \mathrm{kg}$ DM in the diet of cows fed $1 \times$ had no effect on total-tract digestibility of NDF but increased acetate and decreased propionate proportion. In the study of Alfonso-Avila et al. (2017) also, soybean oil at $20 \mathrm{~g} / \mathrm{kg} \mathrm{DM}$ in a high-concentrate diet tended to increase the acetate-to-propionate ratio. In other studies, supplementation of high-forage diets with plant oils at $40 \mathrm{~g} / \mathrm{kg}$ DM had no effect (Kalscheur et al., 1997) or decreased (Benchaar et al., 2015) the acetate-to-propionate ratio in the rumen.

\section{DMI and Milk Performance}

Dry matter intake was not influenced by reduced frequency of TMR delivery to the cows fed CON or YGO diets; this has also been observed in previous studies when the FF of a high-forage diet was increased from twice to more than twice daily (Thivierge et al., 2002; Alzahal et al., 2006; Crossley et al., 2018) or from once to twice daily (Niu et al., 2014). In other works (Le Liboux and Peyraud, 1999; Rottman et al., 2014) with dietary conditions similar to those of the current study ( $\geq 600 \mathrm{~g} / \mathrm{kg}$ of DM forage), the cows fed less frequently exhibited lower DMI. The variation in results may partly be attributed to the production level of cows. The lack of DMI differences was in accordance with no significant differences in daily eating time or eating rate of cows fed $3 \times$ or $1 \times$ in this study, in agreement with previous work (Crossley et al., 2018). In a meta-analysis, supplemental fats at $>42 \mathrm{~g} / \mathrm{kg}$ DM depressed DMI in cattle (Patra, 2013). Beauchemin et al. (2009) also suggested that the amount of fat supplements added to diets should be limited to $40 \mathrm{~g} / \mathrm{kg}$ DM to prevent negative effects on DMI and animal performance. In the present study, YO supplementation had no effect on DMI in cows fed $3 \times$ or $1 \times$. In previous studies in which lactating cows received diets once a day, feeding plant oils rich in 18:2n-6 (up to $40 \mathrm{~g} / \mathrm{kg} \mathrm{DM}$ ) decreased (Boerman and Lock, 2014; Boerman et al., 2014) or had no effect on DMI (Kalscheur et al., 1997; Ramirez Ramirez et al., 2015; Alfonso-Avila et al., 2017).

Feeding $1 \times$ in this study did not decrease milk, FCM, or ECM yields, in accordance with the lack of changes in DMI. Previous works (Alzahal et al., 2006; Niu et al., 
2014; Crossley et al., 2018) also did not observe any effect of FF on milk production. Recently, Johnston and DeVries (2018) in a multistudy analysis demonstrated that each additional meal per day in high-producing dairy cows tended to increase DMI by $0.2 \mathrm{~kg} / \mathrm{d}$ and milk yield by $0.3 \mathrm{~kg} / \mathrm{d}$.

Feeding multiple times per day has been reported to increase milk fat yield, presumably through more equal access to fresh feed and reduction of the diurnal fluctuations in ruminal pH (French and Kennelly, 1990; Shabi et al., 1999; Rottman et al., 2014). However, the effects of FF on milk fat production can be variable, depending upon dietary forage content; a greater benefit may be obtained from more frequent feeding in high(French and Kennelly, 1990; Macmillan et al., 2017) or medium-concentrate diets (Shabi et al., 1999). In the present study, with $600 \mathrm{~g} / \mathrm{kg}$ of diet DM as forage, milk fat concentration and yield decreased with a decrease in $\mathrm{FF}$ in $\mathrm{CON}$ cows, which can partly be explained by decreases in evening ruminal $\mathrm{pH}$. A previous work also reported that an increase in $\mathrm{FF}$ from once to 4 times a day caused a decrease in antilipogenic intermediates of ruminal biohydrogenation of polyunsaturated FA and a concomitant increase in milk fat yield (Rottman et al., 2014). In this study, feeding $25 \mathrm{~g} / \mathrm{kg}$ DM of YO mitigated the negative effects of decreased $\mathrm{FF}$ on milk fat concentration $(P=0.14)$ and yield $(P=0.27)$ for cows fed $1 \times$, which suggests that oil supplementation in low-FF conditions can be beneficial to supply milk fat synthesis in lactating cows fed a high-forage diet. A causative relationship between ruminal biohydrogenation pathway intermediates (ca. trans-10,cis-12 CLA or trans-10 18:1) and depression in milk fat has been demonstrated in cows fed high-concentrate rations and plant oil supplement (Vazirigohar et al., 2014). In previous studies, neither milk fat trans-10, cis-12 CLA concentration nor milk fat yield was influenced by inclusion of plant oils rich in 18:2n-6 (up to $20 \mathrm{~g} / \mathrm{kg} \mathrm{DM}$ ) in the high- (Alfonso-Avila et al., 2017) or mediumconcentrate diets (Ramirez Ramirez et al., 2015) of cows fed once per day.

\section{CONCLUSIONS}

In this study, cows fed CON diets $1 \times$ daily spent more time eating during the first $6 \mathrm{~h}$ after feeding at $0800 \mathrm{~h}$ compared with those fed CON diets $3 \times$; inclusion of YO in the diet reduced the eating time during this time period for cows fed $1 \times$. Cows fed $1 \times-\mathrm{CON}$ consumed larger meals throughout the day compared with the cows fed $3 \times-\mathrm{CON}$ or $1 \times$-YGO. Decreasing $\mathrm{FF}$ reduced ruminal $\mathrm{pH}$ in the evening, regardless of oil supplementation. Dry matter intake and milk yield were similar among the groups. Decreasing FF reduced milk fat yield and content for CON cows, but including $\mathrm{YO}$ in the diet numerically increased milk fat content and yield in cows fed $1 \times$. This study suggests that infrequent feeding of diets containing plant oil may be useful for improving ruminal $\mathrm{pH}$ and milk fat in latelactation dairy cows fed a high-forage diet, presumably by changing feeding behaviors.

\section{ACKNOWLEDGMENTS}

This study was supported by the University of Zanjan (Zanjan, Iran) and the Ministry of Science, Research, and Technology (Tehran, Iran). The authors thank the staff at the Dairy Research Farm of the University of Zanjan for their assistance with animal handling and sample collection. The authors have not stated any conflicts of interest.

\section{REFERENCES}

Acatincai, S., D. Gavojdian, N. Pacala, and L. T. Cziszter. 2010. Relationship between the number of meals per day and rumination process in dairy cows. Lucrari Stiintifice Universitatea de Stiinte Agricole si Med. Vet. Seria Zootehnie 53:336-339.

Alfonso-Avila, A. R., E. Baumann, É. Charbonneau, P. Y. Chouinard, G. F. Tremblay, and R. Gervais. 2017. Interaction of potassium carbonate and soybean oil supplementation on performance of early-lactation dairy cows fed a high-concentrate diet. J. Dairy Sci. 100:9007-9019. https://doi.org/10.3168/jds.2017-13077.

Alzahal, H., J. L. Benford, T. Widowski, J. P. Walton, J. C. Plaizier, T. Duffield, N. E. Odongo, and B. W. McBride. 2006. Effects of frequency of feed delivery on dairy cattle behavior. Prof. Anim. Sci. 22:80-83. https://doi.org/10.15232/S1080-7446(15)31064-0.

AOAC. 1990. Official Methods of Analysis. 12th ed. Association of Official Analytical Chemists, Washington, DC.

Beauchemin, K., T. A. McAllister, and S. M. McGinn. 2009. Dietary mitigation of enteric methane from cattle. Perspect. Agric. Vet. Sci. Nutr. Nat. Resour. 4:1-18. https://doi.org/10.1079/ PAVSNNR20094035.

Beauchemin, K. A., L. Eriksen, P. Nørgaard, and L. M. Rode. 2008. Short communication: Salivary secretion during meals in lactating dairy cattle. J. Dairy Sci. 91:2077-2081. https://doi.org/10.3168/ jds.2007-0726.

Beauchemin, K. A., W. Z. Yang, and L. M. Rode. 2003. Effects of particle size of alfalfa-based dairy cow diets on chewing activity, ruminal fermentation, and milk production. J. Dairy Sci. 86:630-643. https://doi.org/10.3168/jds.S0022-0302(03)73641-8.

Bell, J. A., J. M. Griinari, and J. J. Kennelly. 2006. Effect of safflower oil, flaxseed oil, monensin, and vitamin E on concentration of conjugated linoleic acid in bovine milk fat. J. Dairy Sci. 89:733-748. https://doi.org/10.3168/jds.S0022-0302(06)72135-X.

Benchaar, C., F. Hassanat, R. Martineau, and R. Gervais. 2015. Linseed oil supplementation to dairy cows fed diets based on red clover silage or corn silage: Effects on methane production, rumen fermentation, nutrient digestibility, $\mathrm{N}$ balance, and milk production. J. Dairy Sci. 98:7993-8008. https://doi.org/10.3168/jds.2015 -9398 .

Benson, J. A., and C. K. Reynolds. 2001. Effects of abomasal infusion of long-chain fatty acids on splanchnic metabolism of pancreatic and gut hormones in lactating dairy cows. J. Dairy Sci. 84:14881500. https://doi.org/10.3168/jds.S0022-0302(01)70182-8.

Boerman, J. P., and A. L. Lock. 2014. Effect of unsaturated fatty acids and triglycerides from soybeans on milk fat synthesis and biohydrogenation intermediates in dairy cattle. J. Dairy Sci. 97:70317042. https://doi.org/10.3168/jds.2014-7966. 
Boerman, J. P., C. L. Preseault, and A. L. Lock. 2014. Effect of dietary antioxidant and increasing corn oil inclusion on milk fat yield and fatty acid composition in dairy cattle. J. Dairy Sci. 97:7697-7705. https://doi.org/10.3168/jds.2013-7701.

Bradford, B. J., K. J. Harvatine, and M. S. Allen. 2008. Dietary unsaturated fatty acids increase plasma glucagon-like peptide- 1 and cholecystokinin and may decrease premeal ghrelin in lactating dairy cows. J. Dairy Sci. 91:1443-1450. https://doi.org/10.3168/ jds.2007-0670.

Choi, B. R., and D. L. Palmquist. 1996. High fat diets increase plasma cholecystokinin and pancreatic polypeptide, and decrease plasma insulin and feed intake in lactating cows. J. Nutr. 126:2913-2919.

Cieslak, A., M. El-Sherbiny, J. Szczechowiak, D. Kowalczyk, E. PersKamczyc, M. Bryszak, P. Szulc, A. Jóźwik, and M. SzumacherStrabel. 2015. Rapeseed and fish oil mixtures supplied at low dose can modulate milk fatty acid composition without affecting rumen fermentation and productive parameters in dairy cows. Anim. Sci. Pap. Rep. 33:357-372.

Crossley, R. E., A. Harlander-Matauschek, and T. J. DeVries. 2018. Mitigation of variability between competitively fed dairy cows through increased feed delivery frequency. J. Dairy Sci. 101:518529. https://doi.org/10.3168/jds.2017-12930.

Curtis, S. E., and K. A. Houpt. 1983. Animal ethology: Its emergence in animal science. J. Anim. Sci. 57:234-247.

Dado, R. G., and M. S. Allen. 1994. Nutrition, feeding and calves. Variation in and relationships among feeding, chewing, and drinking variables for lactating dairy cows. J. Dairy Sci. 77:132-144. https://doi.org/10.3168/jds.S0022-0302(94)76936-8.

De Visser, H., S. Tamminga, and L. G. M. van Gils. 1982. Further studies on the effect of fat supplementation of concentrates fed to lactating dairy cows. 1. Effect on feed intake, feed intake pattern and milk production and composition. Neth. J. Agric. Sci. 30:3347-3352.

DeVries, T. J., K. A. Beauchemin, F. Dohme, and K. S. SchwartzkopfGenswein. 2009. Repeated ruminal acidosis challenges in lactating dairy cows at high and low risk for developing acidosis: Feeding, ruminating, and lying behavior. J. Dairy Sci. 92:5067-5078. https: //doi.org/10.3168/jds.2009-2102.

DeVries, T. J., and M. A. G. von Keyserlingk. 2005. Time of feed delivery affects the feeding and lying patterns of dairy cows. J. Dairy Sci. 88:625-631. https://doi.org/10.3168/jds.S0022-0302(05)72726 -0 .

DeVries, T. J., M. A. G. von Keyserlingk, and K. A. Beauchemin. 2005. Frequency of feed delivery affects the behavior of lactating dairy cows. J. Dairy Sci. 88:3553-3562. https://doi.org/10.3168/ jds.S0022-0302(05)73040-X.

Dhiman, T. R., M. S. Zaman, I. S. MacQueen, and R. L. Boman. 2002. Influence of corn processing and frequency of feeding on cow performance. J. Dairy Sci. 85:217-226. https://doi.org/10.3168/ jds.S0022-0302(02)74070-8.

Dürst, B., M. Senn, and W. Langhans. 1993. Eating patterns of lactating dairy cows of three different breeds fed grass ad lib. Physiol. Behav. 54:625-631. https://doi.org/10.1016/0031-9384(93)90069 $-\mathrm{R}$.

French, N., and J. J. Kennelly. 1990. Effects of feeding frequency on ruminal parameters, plasma insulin, milk yield, and milk composition in Holstein cows. J. Dairy Sci. 73:1857-1863. https://doi.org/ 10.3168/jds.S0022-0302(90)78866-2.

Hart, K. D., B. W. McBride, T. F. Duffield, and T. J. DeVries. 2014. Effect of frequency of feed delivery on the behavior and productivity of lactating dairy cows. J. Dairy Sci. 97:1713-1724. https://doi .org/10.3168/jds.2013-7504.

Harvatine, K. J., and M. S. Allen. 2006. Effects of fatty acid supplements on feed intake, and feeding and chewing behavior of lactating dairy cows. J. Dairy Sci. 89:1104-1112. https://doi.org/10 .3168/jds.S0022-0302(06)72178-6.

Heinrichs, J. H., D. L. Palmquist, and H. R. Conrad. 1982. Feed intake patterns of cows fed high fat grain mixtures. J. Dairy Sci. 65:13251328. https://doi.org/10.3168/jds.S0022-0302(82)82348-5.

Humer, E., R. M. Petri, J. R. Aschenbach, B. J. Bradford, G. B. Penner, M. Tafaj, K.-H. Südekum, and Q. Zebeli. 2018. Invited re- view: Practical feeding management recommendations to mitigate the risk of subacute ruminal acidosis in dairy cattle. J. Dairy Sci. 101:872-888. https://doi.org/10.3168/jds.2017-13191.

Johnston, C., and T. J. DeVries. 2018. Short communication: Associations of feeding behavior and milk production in dairy cows. J. Dairy Sci. 101:3367-3373. https://doi.org/10.3168/jds.2017-13743.

Kalscheur, K. F., B. B. Teter, L. S. Piperova, and R. A. Erdman. 1997. Effect of fat source on duodenal flow of trans-C18:1 fatty acids and milk fat production in dairy cows. J. Dairy Sci. 80:2115-2126. https://doi.org/10.3168/jds.S0022-0302(97)76157-5.

Kargar, S., G. R. Ghorbani, M. Alikhani, M. Khorvash, L. Rashidi, and D. J. Schingoethe. 2012. Lactational performance and milk fatty acid profile of Holstein cows in response to dietary fat supplements and forage:concentrate ratio. Livest. Sci. 150:274-283. https://doi.org/10.1016/j.livsci.2012.09.015.

Kargar, S., M. Khorvash, G. R. Ghorbani, M. Alikhani, and W. Z. Yang. 2010. Short communication: Effects of dietary fat supplements and forage:concentrate ratio on feed intake, feeding, and chewing behavior of Holstein dairy cows. J. Dairy Sci. 93:42974301. https://doi.org/10.3168/jds.2010-3168.

Kononoff, P. J., A. J. Heinrichs, and D. R. Buckmaster. 2003. Modification of Penn State forage and total mixed ration particle separator and the effects of moisture content on its measurement. J. Dairy Sci. 86:1858-1863. https://doi.org/10.3168/jds.S0022 -0302(03)73773-4.

Le Liboux, S., and J. L. Peyraud. 1999. Effect of forage particle size and feeding frequency on fermentation patterns and sites and extent of digestion in dairy cows fed mixed diets. Anim. Feed Sci. Technol. 76:297-319. https://doi.org/10.1016/S0377-8401(98)00220-X.

Leonardi, C., and L. E. Armentano. 2003. Effect of quantity, quality, and length of alfalfa hay on selective consumption by dairy cows. J. Dairy Sci. 86:557-564. https://doi.org/10.3168/jds.S0022 -0302(03)73634-0.

Lodge-Ivey, S. L., J. Browne-Silva, and M. B. Horvath. 2009. Technical note: Bacterial diversity and fermentation end products in rumen fluid samples collected via oral lavage or rumen cannula. J. Anim. Sci. 87:2333-2337. https://doi.org/10.2527/jas.2008-1472.

Macmillan, K., X. Gao, and M. Oba. 2017. Increased feeding frequency increased milk fat yield and may reduce the severity of subacute ruminal acidosis in higher-risk cows. J. Dairy Sci. 100:1045-1054. https://doi.org/10.3168/jds.2016-11337.

Mäntysaari, P., H. Khalili, and J. Sariola. 2006. Effect of feeding frequency of a total mixed ration on the performance of high-yielding dairy cows. J. Dairy Sci. 89:4312-4320. https://doi.org/10.3168/ jds.S0022-0302(06)72478-X.

Miller-Cushon, E. K., and T. J. DeVries. 2017. Feed sorting in dairy cattle: Causes, consequences, and management. J. Dairy Sci. 100:4172-4183. https://doi.org/10.3168/jds.2016-11983.

Mirzaei-Alamouti, H., S. Moradi, Z. Shahalizadeh, M. Razavian, H. Amanlou, T. Harkinezhad, I. Jafari-Anarkooli, C. Deiner, and J. R. Aschenbach. 2016. Both monensin and plant extract alter ruminal fermentation in sheep but only monensin affects the expression of genes involved in acid-base transport of the ruminal epithelium. Anim. Feed Sci. Technol. 219:132-143. https://doi.org/10.1016/j anifeedsci.2016.06.009

Morvay, Y., A. Bannink, J. France, E. Kebreab, and J. Dijkstra. 2011. Evaluation of models to predict the stoichiometry of volatile fatty acid profiles in rumen fluid of lactating Holstein cows. J. Dairy Sci 94:3063-3080. https://doi.org/10.3168/jds.2010-3995.

Munksgaard, L., M. B. Jensen, L. J. Pedersen, S. W. Hansen, and L. Matthews. 2005. Quantifying behavioural priorities - Effects of time constraints on behaviour of dairy cows, Bos taurus. Appl. Anim. Behav. Sci. 92:3-14. https://doi.org/10.1016/j.applanim 2004.11.005.

Niu, M., Y. Ying, P. A. Bartell, and K. J. Harvatine. 2014. The effects of feeding time on milk production, total-tract digestibility, and daily rhythms of feeding behavior and plasma metabolites and hormones in dairy cows. J. Dairy Sci. 97:7764-7776. https://doi .org/10.3168/jds.2014-8261.

NRC (National Research Council). 2001. Nutrient Requirements of Dairy Cattle. 7th ed. National Academies Press, Washington, DC. 
Owens, F. N., and M. Basalan. 2016. Ruminal fermentation. Pages 63102 in Rumenology. D. D. Millen, M. B. Arrigoni, and R. D. L. Pacheco, ed. Springer International Publishing, Cham, Switzerland.

Patra, A. K. 2013. The effect of dietary fats on methane emissions, and its other effects on digestibility, rumen fermentation and lactation performance in cattle: A meta-analysis. Livest. Sci. 155:244-254. https://doi.org/10.1016/j.livsci.2013.05.023.

Patra, A. K. 2014. A meta-analysis of the effect of dietary fat on enteric methane production, digestibility and rumen fermentation in sheep, and a comparison of these responses between cattle and sheep. Livest. Sci. 162:97-103. https://doi.org/10.1016/j.livsci 2014.01.007.

Patra, A. K., and Z. Yu. 2013. Effects of coconut and fish oils on ruminal methanogenesis, fermentation, and abundance and diversity of microbial populations in vitro. J. Dairy Sci. 96:1782-1792. https:/ /doi.org/10.3168/jds.2012-6159.

Phillips, C. J. C., and M. I. Rind. 2001. The effects of frequency of feeding a total mixed ration on the production and behavior of dairy cows. J. Dairy Sci. 84:1979-1987. https://doi.org/10.3168/ jds.S0022-0302(01)74641-3.

Pi, Y., L. Ma, K. M. Pierce, H. R. Wang, J. C. Xu, and D. P. Bu. 2019. Rubber seed oil and flaxseed oil supplementation alter digestion, ruminal fermentation and rumen fatty acid profile of dairy cows. Animal 13:2811-2820. https://doi.org/10.1017/ S175173111900137X.

Ramirez Ramirez, H. A., E. Castillo Lopez, K. J. Harvatine, and P. J. Kononoff. 2015. Fat and starch as additive risk factors for milk fat depression in dairy diets containing corn dried distillers grains with solubles. J. Dairy Sci. 98:1903-1914. https://doi.org/ $10.3168 /$ jds.2014-8528.

Ramirez Ramirez, H. A., K. J. Harvatine, and P. J. Kononoff. 2016. Short communication: Forage particle size and fat intake affect rumen passage, the fatty acid profile of milk, and milk fat production in dairy cows consuming dried distillers grains with solubles. J. Dairy Sci. 99:392-398. https://doi.org/10.3168/jds.2015-10006.

Robinson, P. H., and C. J. Sniffen. 1985. Forestomach and whole tract digestibility for lactating dairy cows as influenced by feeding frequency. J. Dairy Sci. 68:857-867. https://doi.org/10.3168/jds .S0022-0302(85)80903-6.

Rottman, L. W., Y. Ying, K. Zhou, P. A. Bartell, and K. J. Harvatine. 2014. The daily rhythm of milk synthesis is dependent on the timing of feed intake in dairy cows. Physiol. Rep. 2:e12049. https:// doi.org/10.14814/phy2.12049.

Shabi, Z., I. Bruckental, S. Zamwell, H. Tagari, and A. Arieli. 1999. Effects of extrusion of grain and feeding frequency on rumen fermentation, nutrient digestibility, and milk yield and composition in dairy cows. J. Dairy Sci. 82:1252-1260. https://doi.org/10.3168/ jds.S0022-0302(99)75348-8.

Shen, J. S., Z. Chai, L. J. Song, J. X. Liu, and Y. M. Wu. 2012. Insertion depth of oral stomach tubes may affect the fermentation parameters of ruminal fluid collected in dairy cows. J. Dairy Sci. 95:5978-5984. https://doi.org/10.3168/jds.2012-5499.

Shingfield, K. J., S. Ahvenjärvi, V. Toivonen, A. Vanhatalo, P. Huhtanen, and J. M. Griinari. 2008. Effect of incremental levels of sunflower-seed oil in the diet on ruminal lipid metabolism in lactating cows. Br. J. Nutr. 99:971-983. https://doi.org/10.1017/ S0007114507853323.

Sjaunja, L. O., L. Baevre, L. Junkkarinen, J. Pedersen, and J. Setälä. 1990. A Nordic proposal for an energy corrected milk (ECM) formula. Pages 156-192 in Performance Recording of Animals: 27th Biennial Session of the International Committee of Animal Recording, Paris, France.

Thivierge, M. C., J. F. Bernier, and H. Lapierre. 2002. Effects of supplemental protein and energy and feeding frequency on the performance of lactating dairy cows fed a protein-deficient diet. Can. J. Anim. Sci. 82:225-231. https://doi.org/10.4141/A01-066.

Tolkamp, B. J., D. P. N. Schweitzer, and I. Kyriazakis. 2000. The biologically relevant unit for the analysis of short-term feeding behavior of dairy cows. J. Dairy Sci. 83:2057-2068. https://doi.org/ 10.3168/jds.S0022-0302(00)75087-9.

Van Keulen, J., and B. A. Young. 1977. Evaluation of acid-insoluble ash as a natural marker in ruminant digestibility studies. J. Anim. Sci. 44:282-287. https://doi.org/10.2527/jas1977.442282x.

Van Soest, P. J., J. B. Robertson, and B. A. Lewis. 1991. Methods for dietary fiber, neutral detergent fiber, and nonstarch polysaccharide in relation to animal nutrition. J. Dairy Sci. 74:3583-3597. https://doi.org/10.3168/jds.S0022-0302(91)78551-2.

Vazirigohar, M., M. Dehghan-Banadaky, K. Rezayazdi, S. J. Krizsan, A. Nejati-Javaremi, and K. J. Shingfield. 2014. Fat source and dietary forage-to-concentrate ratio influences milk fatty-acid composition in lactating cows. Animal 8:163-174. https://doi.org/10 $.1017 /$ S175173111300181X.

Vazirigohar, M., M. Dehghan-Banadaky, K. Rezayazdi, A. Nejati-Javaremi, H. Mirzaei-Alamouti, and A. K. Patra. 2018. Short communication: Effects of diets containing supplemental fats on ruminal fermentation and milk odd- and branched-chain fatty acids in dairy cows. J. Dairy Sci. 101:6133-6141. https://doi.org/10.3168/ jds.2017-14189.

Wangsness, P. J., L. E. Chase, A. D. Peterson, T. G. Hartsock, D. J. Kellmel, and B. R. Baumgardt. 1976. System for monitoring feeding behavior of sheep. J. Anim. Sci. 42:1544-1549. https://doi.org/ 10.2527/jas1976.4261544x.

Weld, K. A., and L. E. Armentano. 2017. The effects of adding fat to diets of lactating dairy cows on total-tract neutral detergent fiber digestibility: A meta-analysis. J. Dairy Sci. 100:1766-1779. https:/ /doi.org/10.3168/jds.2016-11500.

\section{ORCIDS}

Hamidreza Mirzaei-Alamouti @ https://orcid.org/0000-0003-2200 $-6449$

Kamran Akbari-Pabandi $\odot$ https://orcid.org/0000-0002-2608-3006

Mohammad Ali Sirjani ำ https://orcid.org/0000-0002-8878-7594

Adam Cieslak $\odot$ https://orcid.org/0000-0001-7518-579X

Amlan Kumar Patra ( https://orcid.org/0000-0003-1410-0902

Mina Vazirigohar ำ https://orcid.org/0000-0002-8595-908X 